\title{
HUBUNGAN ANTARA CELL DEATH DENGAN VASKULARISASI DAN REAKSI LIMFOSIT PADA KANKER SERVIKS JENIS SQUAMOUS CELL CARCINOMA
}

\author{
Bramantyas Kusuma Hapsari \\ Departemen Histologi Fakultas Kedokteran dan Ilmu Kesehatan Universitas Muhammadiyah Yogyakarta, \\ Jl. Lingkar Selatan Tamantirto Kasihan Bantul Yogyakarta 55182, Telp: (0274) 387656 Ext. 213, Fax: (0274) 387658. \\ Email : bram_sari@yahoo.com
}

\begin{abstract}
Abstrak
Latar Belakang: Kanker serviks merupakan masalah kesehatan yang menempati angka kejadian dan angka kematian tertinggi ke 4 di dunia sedangkan di Indonesia menjadi penyebab kematian di urutan ke 2. Sekitar 80\% - 90\% dari kanker servik adalah jenis Squamous Cell Carcinoma(SCC).Kematian sel (cell death) dapat diakibatkan oleh hipoksia jaringan dan sel-sel limfosit yang akan menyerang tubuh sendiri yang di anggap sebagai antigen.

Tujuan Penelitian: Mengetahui biological behavior sel-sel kanker serviks jenis Squamous Cell Carcinoma berkaitan dengan cell death, vaskularisasi, dan reaksi limfosit

Metode: Desainpenelitianiniadalahcross sectional. Data penelitian ini adalah data sekunder dari rekam medis dan preparat pulasan Hematoksilin Eosin dari sel endotel kanker serviks yang didapatkan dari laboratorium Patologi Anatomi Asri Medical Center(AMC) dan Cito Yogyakarta periode Januari 2013 - April 2014.

Hasil Penelitian: Berdasarkan data yang diambil di AMC dan Lab Cito Yogyakarta periode 2013 - 2014 didapatkan 13 sampel penelitian.Tidakditemukankorelasi yang bermaknaantaracell death denganvaskularisasi $(p=0.14)$ sertahubungan cell death danjumlahlimfosit $(p=0.34)$.

Kesimpulan: Tidak terdapat hubungan antara cell death dengan vaskularisasi ataupun hubungan yang signifikan antara cell death dengan reaksi limfosit pada kanker serviks jenis SCC.
\end{abstract}

Kata kunci: cell death,vaskularisasi, limfosit, squamous cell carcinoma 


\section{Abstract}

Background: Cervical cancer is one of health problem that leading cause of the incidence and deathworldwide, while in Indonesia the cause of death in order to 2. An estimated $80 \%$ - 90\% of cervical cancer is a type of Squamous Cell Carcinoma (SCC). Cell death can be caused by tissue hypoxia and lymphocyte cells that will attack the body itself that is considered as an antigen.

Objective: To identify biological behavior of cancer cells Cervical Squamous Cell Carcinoma types associated with cell death, vascularization, and lymphocyte reaction.

Methods: A cross sectional survey was performed.Medical record and slide of hematoxylin eosin staining of endothelial cells were obtained from cervical cancer laboratory Asri Anatomical Pathology Medical Center (AMC) and Cito Yogyakarta period January 2013 - April 2014.

Results: Sample collection was 13 samples from AMC and Cito Lab Yogyakarta. There was no significant correlation between cell death with vascularization $(p=0: 14)$ and the relationship of cell death and the number of lymphocytes $(\mathrm{p}=0.34)$.

Conclusions: There was no relationship either between cell death with vascularization or a significant relationship between cell death and the reaction of lymphocytes in cervical cancer types SCC.

Key words: cell death, vascularization, lymphocyte, squamous cell carcinoma 


\section{PENDAHULUAN}

Kanker serviks merupakan salah satu masalah kesehatan pada perempuan yang menempati angka kejadian dan angka kematian tertinggi ke 4 di dunia dengan angka kematian lebih dari 288.000 wanita tiap tahunnya. Sekitar 70\% angka kematian terjadi di negara berkembang dan angka kejadian terbanyak terdapat sub-sahara afrika. ${ }^{14}$ Sedangkan di Indonesia sendiri kanker servik berada di urutan ke 2, disusul oleh kanker hati dan saluran empedu intrahepatik, leukemia dan limfoma non hodgin, sedangkan urutan pertama adalah kanker payudara. ${ }^{3}$

Terdapat 2 jenis kanker serviks yaitu, Squamous Cell Carcinoma (SCC) dan adenocarcinoma. Sekitar 80\% - 90\% dari kanker servik adalah jenis SCC. SCC adalah kanker yang berkembang di sel squamous yang melapisi bagian permukaan dari exocervix dan adenocarcinoma adalah kanker yang berkembang dari produksi mukus sel gland di endocervix. ${ }^{2}$

Cell death dapat diklasifikasikan berdasarkan gambaran morfologi (apoptosis, nekrosis, autophagic atau yang berhubungan dengan mitosis), kriteria enzymologikal, aspek fungsional, dan karakteristik imunologikal. ${ }^{4}$ Bentuk utama dari kematian sel adalah kematian sel yang terprogram yaitu, apoptosis dan sangat berkontribusi pada kejadian kanker, gangguan autoimun, infeksi dan gangguan generatif. ${ }^{11}$

Kematian sel juga dapat diakibatkan oleh hipoksia jaringan yang nantinya akan memicu hypoxiainducible factor-1 (HIF-1). Adanya HIF-1 juga dapat mengendalikan transkripsi vascular endhotelial growth factor (VEGF ). Adanya VEGF maka akan terbentuklah neovaskularisasi, neovaskularisasi memiliki efek ganda pada pertumbuhan tumor : Perfusi menyalurkan nutrien dan oksigen, dan sel endotel yang baru terbentuk merangsang pertumbuhan sel tumor disekitarnya dengan mengelurakan berbagai polipeptida. ${ }^{2}$

Hal lain yang harus diperhatikan adalah jumlah limfosit. Pada kondisi neoplastik tubuh memiliki sistem pertahanan imunitas yang akan menghancurkan antigen (benda asing) ditubuh karena, tubuh sendiri mempresentasikan sel yang sudah terinfeksi sebagai benda asing yang harus dihancurkan . Sel sistem imun yang ada ditubuh terdiri dari Limfosit T, Limfosit B, Makrofag,interleukin (IL) dan sel natural killer. ${ }^{7}$

Berdasarkan uraian diatas, dapat diketahui bahwa terjadinya kematian sel dapat terjadi oleh karena 2 hal, pertama dikarenakan oleh hipoksia jaringan, yang nantinya hipoksia juga dapat memicu timbulnya VEGF dan terjadilah angiogenesis. Dan yang kedua adalah karena sel-sel limfosit akan menyerang tubuh sendiri yang dianggap sebagai antigen. Oleh karena itu, peneliti ingin mengetahui biological behavior sel-sel kanker serviks jenis Squamous Cell Carcinoma berkaitan dengan hubungan antara cell deathdengan vaskularisasi dan jumlah limfosit pada jenis kanker serviks ini.

\section{METODE PENELITIAN}

Desain penelitian yang diambil untuk penelitian ini adalah non-eksperimental dengan pendekatan cross sectional. Data dalam penelitian ini adalah data sekunder karena berasal dari rekam medis dan preparat pulasan Hematoksilin Eosin dari sel endotel kanker serviks yang didapatkan dari laboratorium Patologi Anatomi Asri Medical Center(AMC) dan Cito Yogyakarta dari bulan Januari 2013 sampai April 2014.

Penelitian ini berpedomana pada prinsip-prinsip etika penelitian, salah satunya adalah Confidentially. Penulis disini menjamin kerahasiaan responden dengan tidak akan memberitahukan kepihak lain dan tidak menulis nama responden pada data penelitian.

Analisis data

Pada penelitian iniakan melihat hubungan antar variabel yaitu satu variabel tergantung (Cell death)dan dua variabel bebas (vaskularisasi dan jumlah limfosit). Uji hipotesis korelatif digunakan untuk mengetahui hubungan antar variabel. Nilai $p<0,05$ digunakan sebagai nilai korelasi yang bermakna antara dua variabel yang diuji. Untuk mengolah semua data inimenggunakan aplikasi SPSS for windows release 18. 


\section{HASIL PENELITIAN}

Berdasarkan data yang diambil di AMC dan Lab Cito Yogyakarta periode 2013 - 2014 didapatkan 13 sampel sebagai subjek penelitian. Hasil pengamatan sampel tersebut didapatkan hasil luasan nekrosis, vaskularisasi, dan jumlah limfosit pada table 1.

Tabel 1. Luasan Nekrosis, Vaskularisasi, dan Jumlah Limfosit

\begin{tabular}{|c|c|c|}
\hline No & Nama Kelompok & Rata-rata \pm SD \\
\hline 1 & Cell death & $9,51 \pm 3,46$ \\
\hline 2 & Vaskularisasi & $1231,49 \pm 980,90$ \\
\hline 3 & Limfosit & $0,11 \pm 0,05$ \\
\hline
\end{tabular}

$\mathrm{SD}=$ Standar defiasi

Penelitian ini juga menunjukkan bahwa tidak ditemukannya hubungan antara cell death dan vaskularisasi ( $p=0.14)$ sertahubungan cell death dan jumlah limfosit $(p=0.34)$

\section{PEMBAHASAN}

Penelitian ini bertujuan untuk mengetahui biological behavior sel-sel kanker serviks jenis Squamous Cell Carcinoma berkaitan dengan cell death, vaskularisasi, dan reaksi limfosit. Hipotesis yang dibuat oleh penulis adalah terdapat hubungan antara cell death dengan vaskularisasi dan cell death dengan limfosit. Sesuai dengan penelitian sebelumnya yang telah dilakukan oleh Ujianto (2010) melaporkan bahwa terdapat hubungan antara jumlah limfosit dengan jaringan tumor, semakin besar tumor maka semakin sedikit jumlah limfositnya.

Pada penelitian ini peneliti memiliki hipotesis bahwa terdapat hubungan antara cell death dengan vaskularisasi pada kanker serviks jenis SCC. Terbentuknya neovaskularisasi pada tumor diakibatkan karena adanya Hypoxia-inducible factor-1á(HIF 1-á) yang diekspresikan dalam kanker pada manusia sebagai akibat dari keadaan hipoksia intratumoral serta sebagai perubahan genetik, seperti mutasi fungsi onkogen (misalnya, ERBB2) dan kerugian fungsi mutasi pada gen supresor tumor (misalnya, VHL dan PTEN). ${ }^{9}$ Dengan adanya terbentuknya neovaskularisasi ini menunjukkan banyaknya sel yang mengalami hipoksia dan ini salah satu penyebab dari terjadinya kematian sel. Dalam keadaan hipoksia, HIF1- á akan masuk dan terakumulasi dalam nukleus (inti sel), dimana HIF ini merupakan tranduksi sinyal ekspresi gen beberapa protein, di antaranya adalah beberapa protein penting bagi sel kanker dalam menginduksi peristiwa angiogenensis sel endotel. ${ }^{6}$

Adanya reaksi transkripsi bcl - 2 mampu untuk mengaktifasi protein HIF 1-á dan VEGF yang dapat memediasi new vascularitation, sehingga berdampak pada pertumbuhan tumor yang lebih agresif. ${ }^{13}$

Pada keadaan normal pergantian dan pembaruan sel terjadi sesuai dengan kebutuhan melalui proliferasi sel dan apoptosis di bawah pengaruh proto-onkogen dan gen supresor tumor. ${ }^{10}$ Bila terjadi gangguan oleh bahan karsinogen yang menyebabkan proto-onkogen berubah menjadi onkogen, maka akan terjadi proliferasi sel abnormal yang tidak diimbangi dengan terjadinya apotosis sel. ${ }^{12}$

Proliferasi yang tidak terkendali menyebabkan ukuran suatu neoplasma atau tumor mencapai ukuran yang lebih besar, sehingga diperlukan pembentukan neovaskularisasi guna mendukung nutrisi jaringan tumor baru, yaitu dengan menstimulasi sekresi polipeptida seperti IGF (Insulin like Growth Factor), PDGF, granulosit macrophage colony stimulating factor (GM-CSF) dan IL-1 (Robbins, 2005).8 Pertumbuhan tumor dikontrol oleh keseimbangan antara faktor angiogenik dan faktor yang menghambat proses angiogenesis.

Kesimpulan dari penelitian ini adalah tidak ditemukannya hubungan antara cell death dengan vaskularisasi danhubungan antara cell death dengan reaksi limfosit pada kanker serviks jenis SCC. Adapun kemungkinan faktor penyebab yang mengakibatkan tidak temukannya hubungan antara cell death dengan vaskularisasi dan jumlah limfosit yaitu: (1) jumlah sampel penelitian yang sangat terbatas, yaitu hanya terdapat 13 sampel kanker serviks jenis SCC yang akan mempengaruhi hasil dari penelitian yang tidak valid, 
dan (2) kesalahan dalam perhitungan luas, baik itu luas tumor, luas vaskularisasi, jumlah limfosit dan nekrosis pada preparat. Oleh karena itu perlu diadakan penelitian dengan jumlah sampel yang lebih banyak dan mencakup populasi yang luas serta dilakukannya penelitian lebih lanjut mengenai Biological Behaviour dari jenis tumor untuk mengetahui tentang reaksi limfosit, vaskularisasi dan cell death.

\section{DAFTAR PUSTAKA}

1.Anoname(2014).Cervical cancer risks and causes.Cancer Research UK. Diaksespadatanggal, 6 April 2014 ,darihttp://www.cancerresearchuk.org/ cancer-help/type/cervical-cancer/about/cervicalcancer-risks-and-causes

2.Anoname (2007).Neoplasma. In Kumar.,Cotran., Robbins (Eds.), Buku Ajar Patologi Robbins ( $7^{\text {th }} \mathrm{ed}$.). Jakarta : EGC.

3.DepartemenKesehatanRepublik Indonesia.(2011, Oktober). Gerakan Perempuan Melawan Kanker Serviks. KementrianKesehatanRepublik Indonesia. Diakses 4 April 2014, darihttp://www.depkes.go.id/ index.php?vw=2\&id $=1668$

4. Kroemer, G., Galluzzi, L., Vandenabeele, P., Abrahams, J., Alnemri, E.S., Baehrecker, E.H., et al. (2009). Classification of cell death.National Institutes of Health, 3-11.

5. Ujianto, Agus. (2010) Jumlah limfosit darah tepi dan sebukan limfosit sekitar jaringan tumor pada penderita keganasan payudara yang mendapatkan injeksi vitamin C. Undip Website.

6. Maxwell, P. 2005. Hypoxia-inducible Factor As a Physiological Regulator. Experimental and Physiology. 90: 791 - 792. Diakses pada tanggal 13 Juli 2014 dari http://ep.physoc.org/content/90/6/ 791.full

7. Mitchell, R. N., \&Kumar, V. (2007).PenyakitImunitas. In Kumar.,Cotran., Robbins (Eds.), Buku Ajar Patologi Robbins ( $7^{\text {th }}$ ed.). Jakarta : EGC.

8. Robbins. 2005. Pathologic Basis of Disease. 7th Edition. International Edition. Pennsylvania; Elsevier.

9. Semenza GL. 2003. Targeting HIF-1 for cancer therapy. Nat Rev Cancer. 3:721 - 732.

10.Silalahi J. 2006. Antioksidan dalam Diet dan Karsiogenesis. Cermin Dunia Kedokteran. 153: 4247.

11.Strasser, A., Cory, S., \& Adams, J. M. (2011). Deciphering the rules of programmed cell death to improve therapy of cancer and other diseases. The EMBO Journal, 3667-3683.

12. Tjandra, L. 2010. Protoonkogen. FK Wijaya Kusuma Surabaya.

13.Trisciuoglio D, Gabellini C, Desideri M, Ziparo E, Zupi G, Del Bufalo D. 2010. Bcl-2 Regulates HIF-1a Protein Stabilization in Hypoxic Melanoma Cells via the Molecular Chaperone HSP90. Plos One; 5(7): e11772.

14.World Health Organization (2013, September).Human papillomavirus (HPV) and cervical cancer.Diakses 8 April 2014, darihttp://www.who.int/ mediacentre/ factsheets/fs380/en/

15.World Health Organization (2013, 12 Desember). Latest world cancer statistics Global cancer burden rises to 14.1 million new cases in 2012. Diakses 2 april 2014, darihttps://www.google.com/url?q=http: //www.iarc.fr/en/ media-centre/pr/2013/pdfs/ pr223_E.pdf\&sa=U\&ei=vdxLU-GGBoPs8AWkw ICYBg\&ved=0CAYQFjAA\&client=internal-udscse\&usg=AFQjCNFdYwbZ7ZSIKZTgx3EpnWe HRY3_Tg 